\title{
Simultaneous Bilateral Radical Neck Dissection Followed by Internal Jugular Vein Reconstruction
}

\author{
Hartono Abdoerrachman *, Bambang Hermani *, Murnizal Dahlan **, Purnaman Sardjono Pandi *.
}

\begin{abstract}
Bilateral radical neck dissection is not a new procedure and had been known long time ago by the experts, but rarely performed due to the undesired and unpleasant complications, especially disturbance in venous return from cranial and cervical region. With respect to the intracranial and other serious complications, attempts were made to maintain the flow of venous drainage from the head and neck region by reconstructing the internal jugular vein. A case of carcinoma of the larynx with bilateral neck nodes metastases was reported and simultaneous radical treatment was conducted by performing simultaneous bilateral radical neck dissection and laryngectomy, followed by reconstruction of left internal jugular vein using savena magna vein. Six month follow up showed no intracranial complication.
\end{abstract}

\begin{abstract}
Abstrak
Diseksi leher radikal bilateral bukanlah prosedur yang baru dan telah lama dikenal oleh para ahli, tetapi jarang dilakukan sebab kemungkinan adanya komplikasi yang tidak diingini, terutama gangguan aliran darah balik dari daerah leher dan kepala. Mengingat komplikasi intrakranial dan komplikasi lokal yang lain, beberapa upaya dilakukan untuk menjaga kelancaran aliran balik darah dari leher dan kepala. Suatu kasus mengenai karsinoma laring dengan penyebaran ke kelenjar limf leher bilateral dilaporkan. Telah dilakukan diseksi leher radikal bilateral secara simultan dan pengangkatan laring, yang kemudian dilanjutkan dengan rekonstruksi vena jugularis interna kiri dengan menggunakan vena safena magna. Follow-up selama 6 bulan tidak menunjukkan adanya komplikasi
\end{abstract}

Keywords: Laryngectomy, Carcinoma of the larynx, Neck nodes metastases

Tumor of the head and neck region is often followed by neck nodes involvement. Tumor that has been spreading to the cervical lymph gland, needs a special consideration in the treatment, depending on the stadium of the tumor, the primary tumor and the location of the spread.

There are several modalities in treating the cervical spread and one of the treatment is radical neck dissection. Radical neck dissection still holds a prominent position and plays a vital role in surgical management of cancer of head and neck to control regional metastatic disease.

Usually neck dissection is performed unilaterally, on the involved side of the neck, while bilateral neck

\footnotetext{
* Department of Otorhinolaryngology, Faculty of Medicine, University of Indonesia/Dr. Cipto Mangunkusumo Hospital, Jakarta, Indonesia

** Department of Surgery, Faculty of Medicine, University of Indonesia/Dr. Cipto Mangunkusumo Hospital, Jakarta, Indonesia
}

dissection is more uncommon in regards to serious complications.

Bilateral neck dissection is not a new procedure, and having been performed by Crile in $1906,{ }^{1}$ Bartlett in $1926{ }^{2}$ and other experts long time ago.

Major complications of bilateral radical neck dissection are related to venous engorgement and increased intracranial pressure, such as facial edema, intracranial hypertension, convulsion, and coma. A very rare case of blindness after bilateral neck dissection had also been reported.

We reported a case with carcinoma of the larynx and bilateral cervical metastasis. To apprehend the intracranial and other serious complications, a joint operation with a vascular surgeon was organized to perform a simultaneous bilateral radical neck dissection, followed by laryngectomy and finally to reconstruct one side of the resected internal jugular vein using saphena magna vein. 


\section{METHOD}

\section{Case}

On June 1987, a man, 65 years of age, was referred to the Department of Otorhinolaryngology, Faculty of Medicine, University of Indonesia, with the complaints of hoarse voice and stridor inspiratoir. Deformity of cervical contour was clearly visible due to swelling on both sides of the neck.

CT-Scan of the larynx and direct laryngoscopy revealed that the tumor involved the supraglottic and glottic region of the larynx. Neck nodes were palpable on both sides of the neck, and fixed to the surrounding tissue. Histological finding of the tumor showed squamous cell carcinoma. Laboratory finding were within normal limits and no metastasis was demonstrated on chest X-photo.

In a joint cancer meeting, it was decided to conduct a joint operation with a vascular surgeon to perform simultaneous bilateral radical neck dissection to secure the radicalization, than followed by jugular vein reconstruction on one side to prevent the unexpected complication, and total laryngectomy.

\section{Surgical procedure}

On June 1987 bilateral radical neck dissection by removing both internal jugular veins was performed under general anesthesia followed by resection of the larynx, as shown in Figure 1-8. Figure 1 showed a wide incision on the skin for extended access of the tumor, followed by bilateral radical neck dissection and extirpation of the larynx, as shown in Figure 2. Figure 3 showed the surgical area afterwards. The vascular surgeon resected the saphena magna vein from the thigh for autograph (Figure 4). The autograph-vein was then placed at the site of the resected left internal jugular vein as shown in Figure 5. After suturing the distal end of the graph (Figure 6), heparin flush was given to prevent clogging by blood clot (Figure 7). Overview of the excized larynx and the reconstructed left internal jugular vein was demonstrated in Figure 8, after closing the hypopharynx. Finally, layer by layer of closing procedure of the wound was performed after the insertion of a haemovac-drain and nasogastric tube.

\section{Monitoring of complications}

The patient was followed-up for 6 months post operatively, to check for the presence of intracranial and local complications.

\section{RESULTS}

One month later when the patient was discharged from the hospital, no intracranial complications were noted. The patient was followed up intensively for 6 months post-operatively and no intracranial or local complications were noted.

\section{DISCUSSION}

Our case had carcinoma of the larynx and bilateral cervical metastasis. The presence of bilateral cervical metastasis was regarded as a sign of inoperability and incurability by many surgeons. Some surgeons suggested bilateral neck dissection, but anatomist declared that ligation of both internal jugular veins was very dangerous. Because of the serious complication and hesitancy in ligating both jugular veins, the operation did not become popular, until some experts, e.g. Mc Guirt and Razack reported their successful experiences. ${ }^{3,4}$ Since that time increasing number of the procedure have been performed, while others are reluctant to perform such a radical and simultaneous procedure for neck dissection due to undesired serious complications. However, sometimes they are confronted to a critical situation that need a difficult decision which sometimes controversial to an established and widely used procedure.

The venous return from cervical region is served mostly by both internal jugular veins and vertebral venous plexus. The studies of investigators documented adequate collateral venous circulation after ligation of both internal jugular veins. The main route of venous drainage in the absence of the jugular veins is the vertebral venous plexus, the emissary veins, and the veins of the posterior cervical region. Figure 9 shows the vertebral venous plexus. ${ }^{5}$

Several complications have been reported by the experts. Therefore the surgeons should be aware of these complications, and when they do occur, deal with them rapidly. Surgical complications, such as fistula formation and carotid artery rupture do occur, but do not occur more frequently than in unilateral radical neck dissection. 


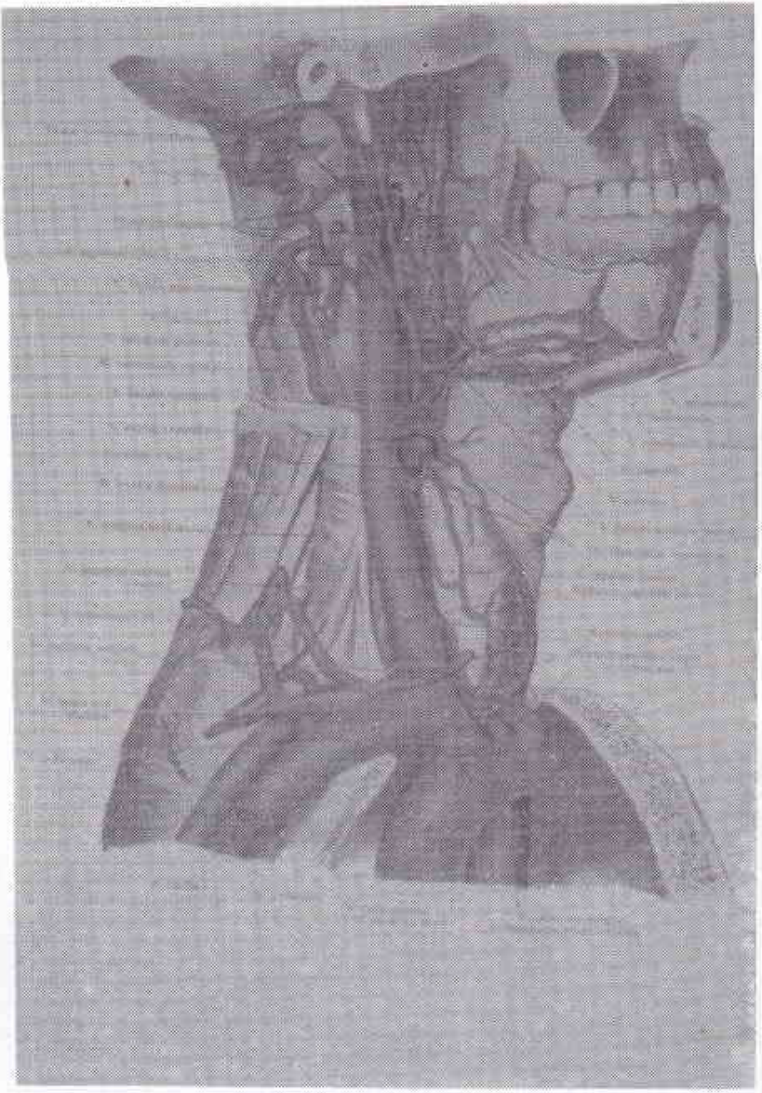

Figure 1. A wide $U$-shape wide skin incision on the neck to provide wide accessibility to the operating field.

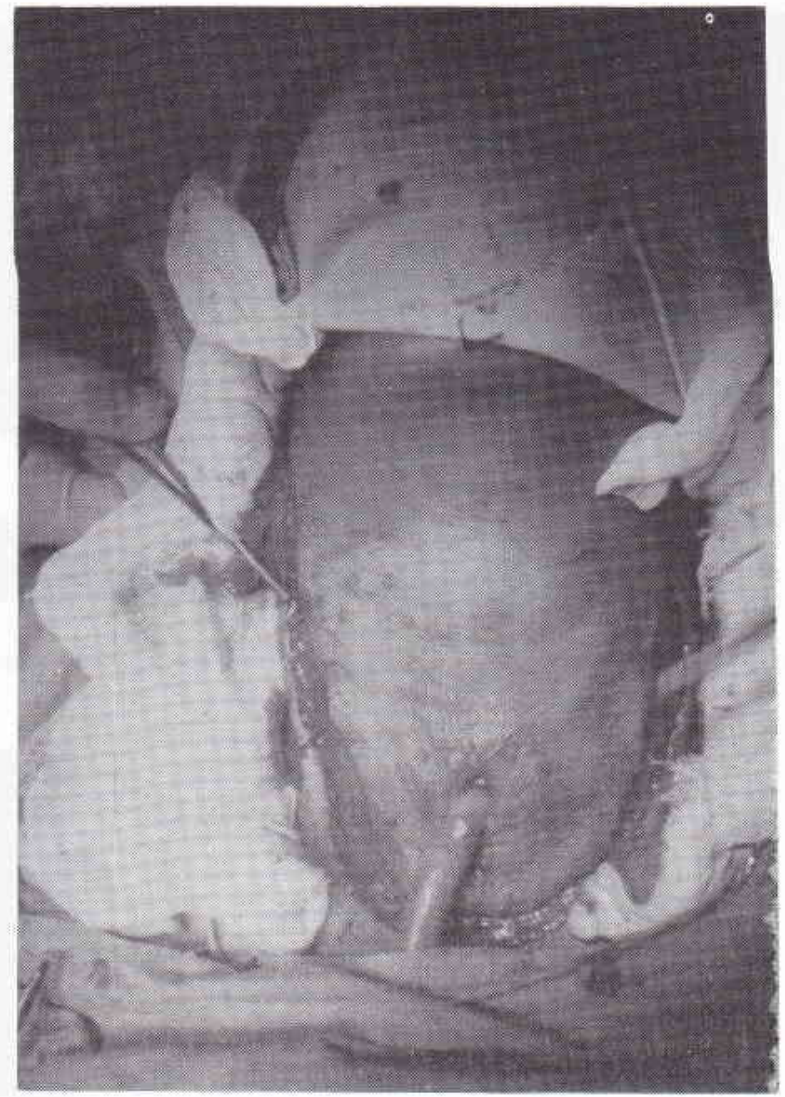

Figure 2. Bilateral radical neck dissection and followed b; extirpation of the larynx.

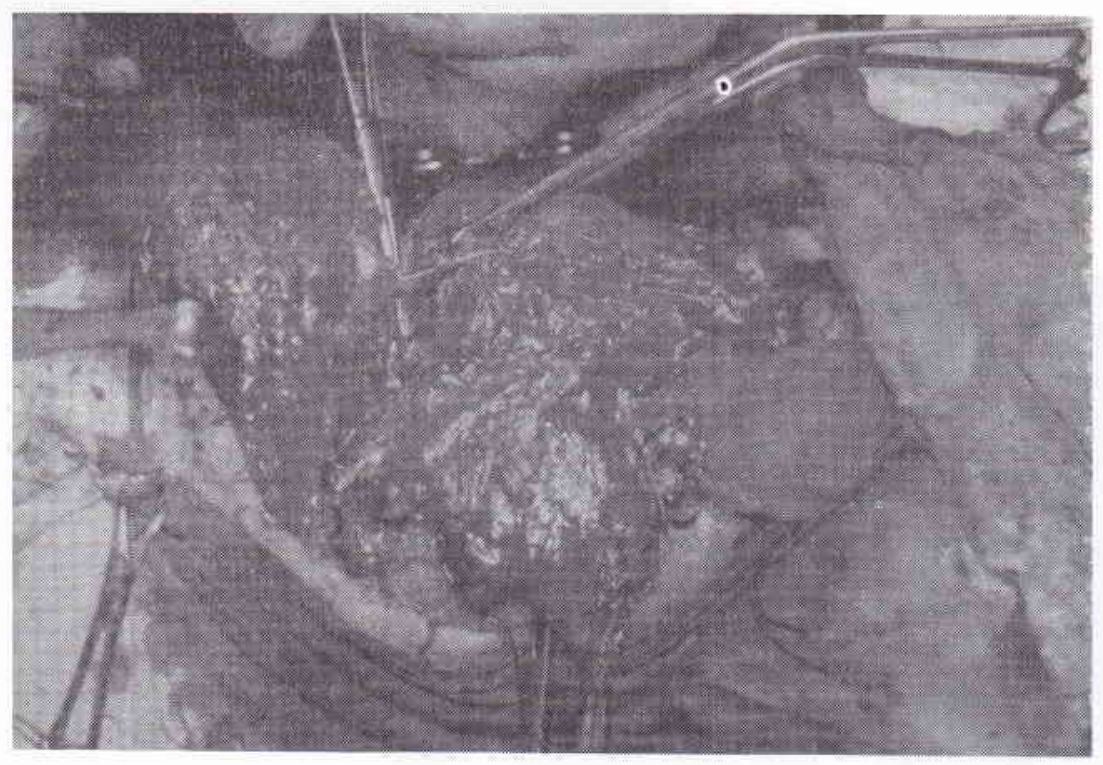

Figure 3. The resected area after dissecting both sides of the neck and the larynx, demonstrating the opening of the hypopharyngeal region with the nasogastric tube passing through. 


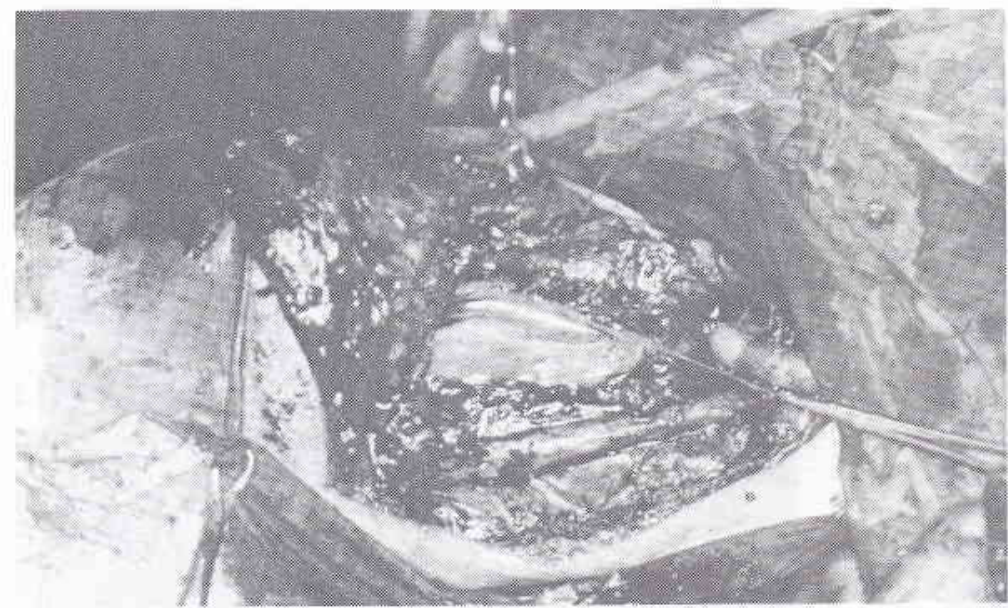

Figure 4. The autograph-vein was taken from the saphena magna vein.

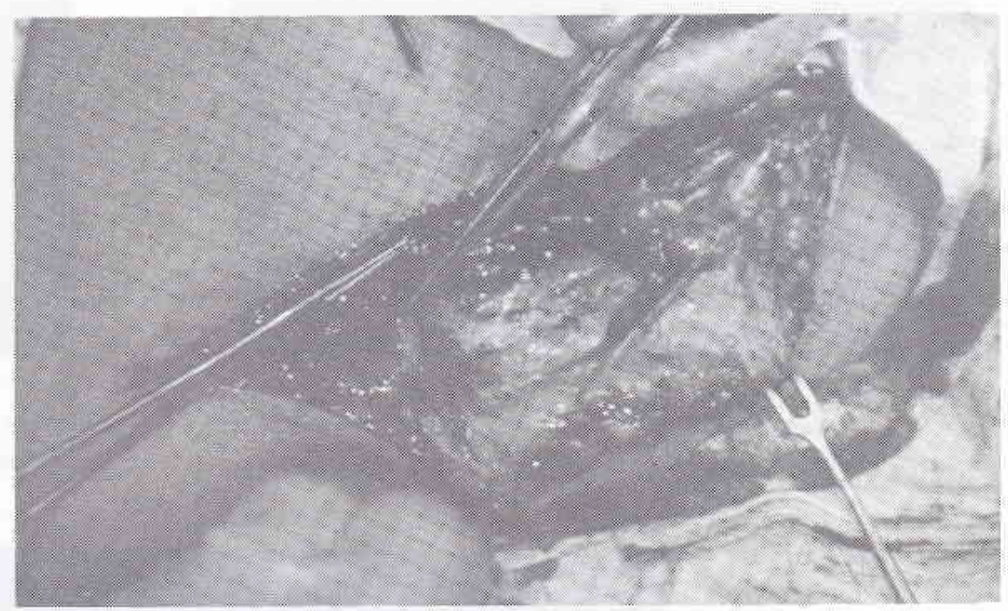

Figure 5. The vein-graph was placed on the resected left internal jugular vein to measure its proper length.

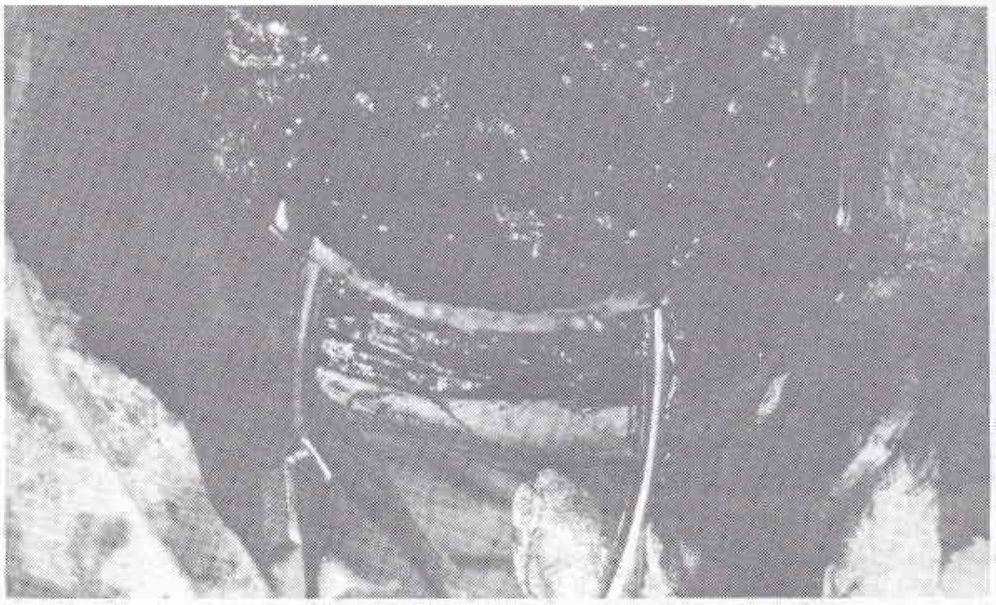

Figure 6. Attachment and suturing of the graph to the distal end of the resected left internal jugular vein. 


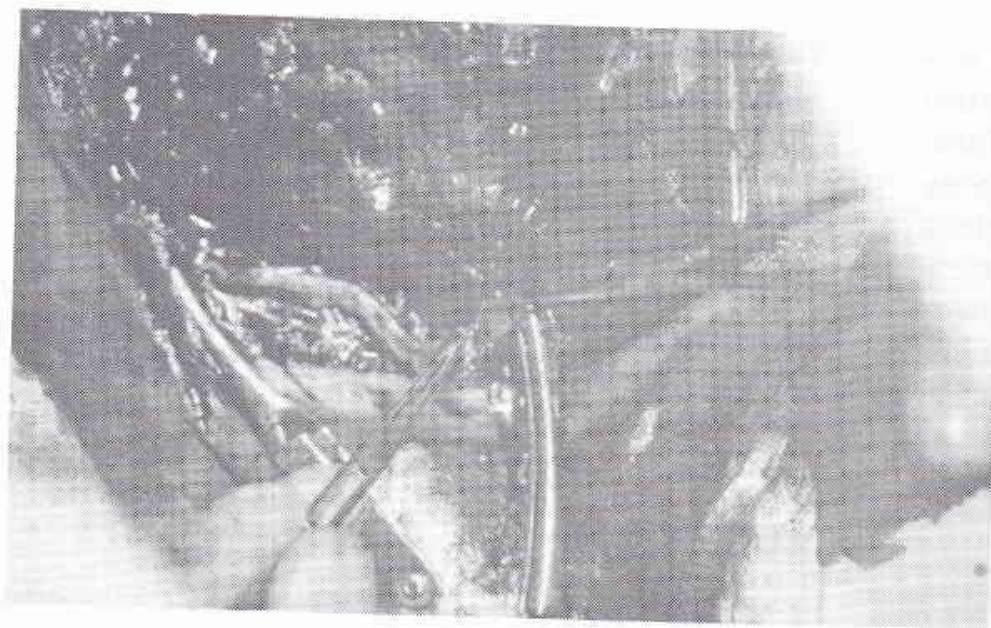
Figure 7 . Flushing the graph by means of heparin to prevent clogging by blood
clot.

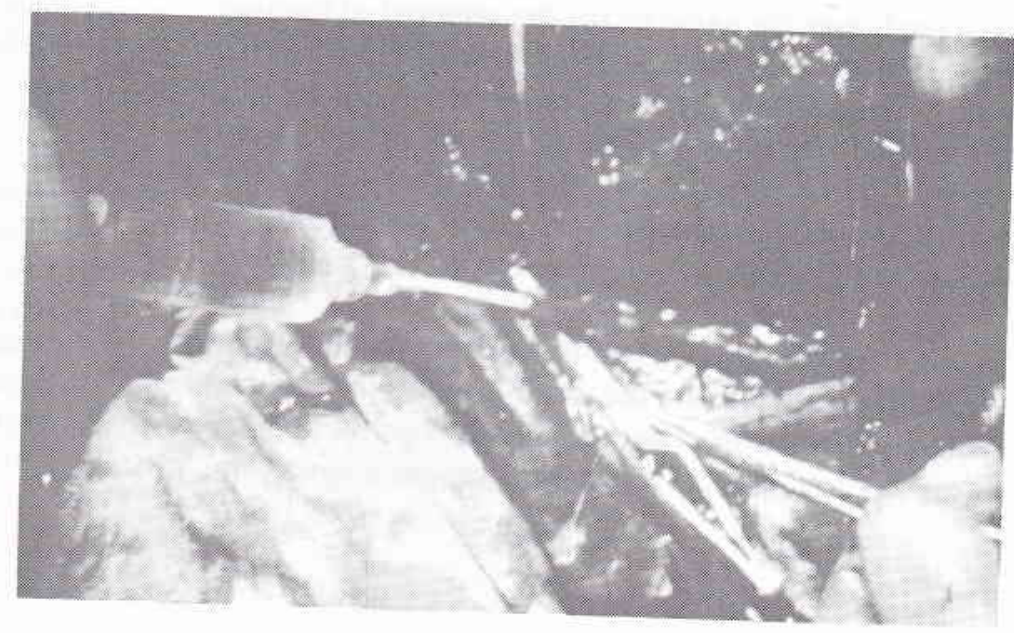

Figure 8. Overview of the excised operating field after closing of the hypopharynx. The reconstructed left internal jugular vein was demonstrated
in front of the arrow.

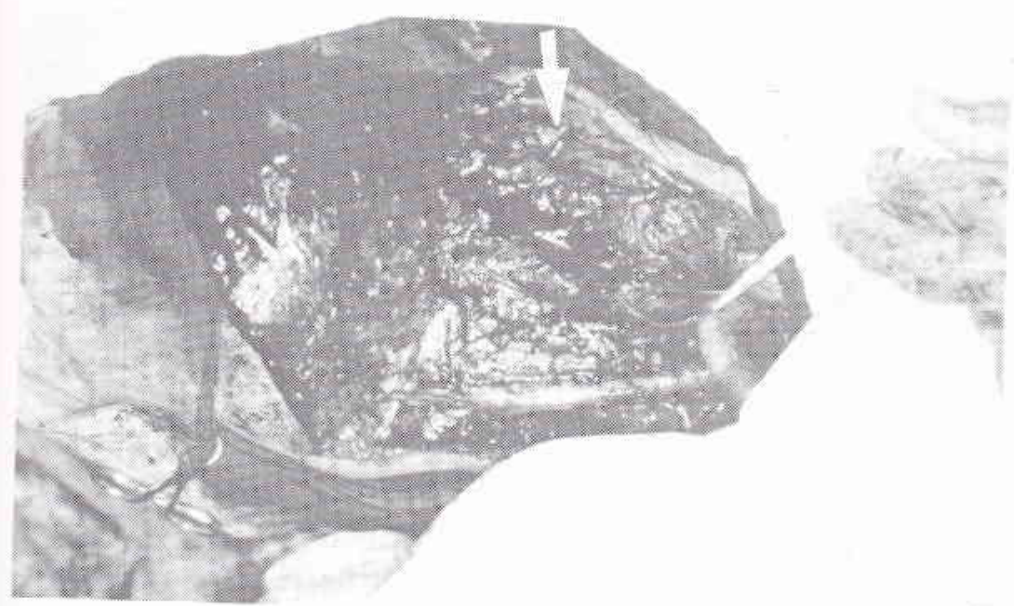

Figure 9. Schematic illustration of the vertebral venous plexus in the neck region, showing the route of venous return besides internal jugular veins. 
Many experts suggested to perform bilateral neck dissection in two stages, while others did a modified simultaneous bilateral neck dissection such as functional neck dissection to prevent the undesired complications. ${ }^{6}$ Razack mentioned that radical block dissection of both sides of the neck in the same patient had been performed as a two stage procedure for many years, with the customary preservation of one internal jugular vein due to the fear of fatal cerebro-vascular complication. To his opinion, careful stripping and preservation of the vein on one side is an acceptable safety measure. ${ }^{4}$

Other writers said that there was no added risk in removing both internal jugular vein. Martin ${ }^{7}$ stated that the indication for removing the second internal jugular vein in a bilateral neck dissection (either simultaneous or staged) was the same as for the removal of the first vein. His experiences in the clinic had shown that there was no increase in post-operative mortality or disability that could be ascribed to the removal of the second internal jugular vein. He believed that a complete neck dissection was not possibie if the vein was not resected.

In this case we did an extra ordinary procedure as an alternative to overcome the disadvantages of wide and extended dissection of the neck, by reconstructing one side of internal jugular vein using saphena magna vein.
Our result showed that the reconstruction of internal jugular vein could prevent intracranial complications.

\section{CONCLUSION}

In wide and extended dissection of the neck, reconstruction of one side of internal jugular vein using saphena magna vein can prevent intracranial complication.

\section{REFERENCES}

1. Crile G. Excision of cancer of the head and neck with special reference to the plan of dissection based on 132 patients. JAMA 1906;47:1780-6.

2. Bartlett EY, Callender CL. Neck Dissection. Surg Clin N Amer 1926;6:481-504.

3. Mc Guirt WF, Mc Cabe BF. Bilateral Radical Neck Dissection. Arch Otolaryngol 1980;106:427-9.

4. Razack MS, Baffi R, Sako K. Bilateral Radical Neck Dissection. Cancer 1985;47:197-9.

5. Spalteholz W. Handatlas der anatomie des menschen. Amsterdam: Scheltema \& Holkema, 1970.

6. Abdoerrachman H, Roesmarjono, Hermani B. Functional Neck Dissection. Kumpulan Naskah IImiah Konggres Nasional PERHATI VII; 1983, August 21-23; Surabaya. Surabaya: Perhati, 1983:846-50.

7. Martin H, Del Valle B, Ehrlich, Cahan WG. Neck Dissection. Cancer 1957;4:441-99. 